УДК 811.153.41’373.611

811.163 .41 '374.81

https://doi.org/10.18485/msc50.2021.2.ch38

Божо Ћорић

\title{
ВАРИЈАЦИЈЕ У ТУМАЧЕЊУ ИЗВЕДЕНИХ РЕЧИ У ЈЕДНОЈЕЗИЧКИМ РЕЧНИЦИМА СРПСКОГ ЈЕЗИКА ${ }^{1}$
}

1. Александар Белић, у својој књизи О језичкој природи и језичком развитку ${ }^{2}$ све речи једног језика дели на праве и неправе. За праве речи је, по њему, карактеристично, поред осталог, то што „немотивисаним комплексом гласова"з обележавају некакав појам (предмет), из чега јасно произилази да такве речи не могу послужити као узор за прављење нових речи. На другој страни, код неправих речи, одговарајући комплекс гласова је мотивисан, тј. у тим речима однос према основној речи, и по структури и по значењу, потпуно је јасан и провидан. Према томе, речи као што су око, зоб, нос, звер итд. су немотивисане, а као такве су и непродуктивне, што се лепо види у поређењу са боровина, буковина, Петров, дрвен и сличним неправим речима; само ове друге могу послужити као узор за грађење нових речи. По Белићу мотивисаност и продуктивност су у тој мери нераздвојне особине да „свако губљење мотивисаности повлачи за собом и стварно губљење продуктивности". ${ }^{4}$ А то даље значи да „неправи” карактер неке речи није вечан. Демонстрирајући ову тезу на именицама, Белић ће констатовати да „није тешко одредити докле ће једна именица чувати карактер неправе именице: све дотле док њен однос према основној речи буде потпуно јасан, докле се значење неправе речи не буде изгубило у новом сложеном значењу дане речи." зилази да неправа реч, било које врсте, може, под одређеним условима, прећи у групацију праве речи, што је, по Белићу, сталан процес. На при-

1 Рад је инспирисан чланком Е. А. Земске, Производные слова в толковых словарях русского языка, Современная русская лексикография 1976, Ленинград, 1977, стр. 111-122.

2 І књига, Београд, 1958.

3 Исто, стр. 36.

4 Исто, стр. 22.

5 Исто, стр. 25. 
мерима као што је именица родитељь или придев главни он показује како мотивисана, односно „полумотивисана” реч креће ка групацији правих, лексичких речи, како, наиме, „продуктивност може бити смањена, ограничена, а може је и сасвим нестати." ${ }^{\prime}$ Друкчије речено: између основинских и изведених речи постоји веза и на плану израза и на плану садржаја, а кад се та веза на било ком плану прекине, губе се мотивисаност и продуктивност, а реч престаје да буде, синхроно гледано, изведена.

2. Изведена реч је препознатљива по својој творбеној структури чије елементе чине: творбено значене, творбена мотивација и творбени формант. Изостанак само једног од ових елемената искључује дату реч из групације деривата. Реч копач несумњиво припада тој групацији, будући да је мотивисана глаголом (копати), да има творбени формант (-ач), а из семантичке интерпретације онај који копа утврђујемо творбено значење у које је, како видимо, уграђена компонента значења основинске речи.

Дакле, у значењу изведене речи уочавамо неку врсту двојног односа, односно поседовање неке врсте двојне референције. Изведенице, на једној страни, поседују, као и све друге речи, референцију према реалном свету, али и референцију према свету речи, што није карактеристично за просте речи. ${ }^{7}$ Просту (праву, лексичку) реч не можемо тако семантички интерпретирати, не можемо, наиме, у дефиницији користити неку јединицу која би са дефинисаном речи имала исти корен. (Реч длан, рецимо, можемо само описно тумачити).

У специфичност изведеница спада и могућност груписања у одређене творбене типове. Изведенице истог творбеног типа показују семантичку истоветност оличену у заједничком форманту, али и одређену смисаону разлику узроковану посебним творбеним основама: копач и свирач припадају истом творбеном типу и истој творбено-семантичкој категорији, али им је смисао различит због различите основе. С друге стране, међу различитим творбеним типовима постоје значењске сличности условљене истом основом, али и разлике условљене различитим формантима (исп. свирач, свирка, свирачица...)

3. Ове специфичности изведеница могу имати одређене реперкусије на избор начина њиховог тумачења. Наиме, могућност улажења у двоструке низове корелација ствара основе за тумачење изведених речи путем диференцијалних ознака: у речнику се протумачи онај део значења

${ }^{6}$ Исто, стр. 54.

7 Исп. Е. С. Кубрякова, Типь языковых значений, Семантика производного слова, Москва, 1981, на стр. 9-10. 
изражен формантом, а онај део значења изражен основом се не тумачи већ се само упућује на основинску реч. Наравно, од састављача речника зависиће у којој ће се мери користити аналогни начини тумачења у односу на речи истог творбеног типа, односно исте творбене структуре.

4. Међутим, јасно је да дефиниције свих изведених речи, формално гледано, не могу бити исте. То су, поред осталих, уочили и чланови редакције за израду Речника САНУ, што се види из њихове констатације у Уводу Огледне свеске $e^{8}$ „3 наче ња су одређивана како код које категорије: на један начин код простих, неизведених речи, на други - код једне групе изведених речи, а на трећи, код друге групе изведених речи". Дакле, уређивачи речника експлицитно указују на могућност двојаког приступа дефинисању групације изведених речи. Узмимо за пример дефинисање неких придева у Огледној свесии:

главичаст пр. 1. Налик на главищу, као главица, са обликом главиนе.

главаров Присвојни придев уз главар.

Видимо да уређивачи речника у првом случају подвргавају дефиницији само онај део значења изведене речи који се изражава творбеним формантом -аст и то значење интерпретирају као: налик на..., као..., са обликом..., а иза тога следи једноставно упућивање на основинску реч главица. У другом случају дефиниција је сасвим типизирана: у њу је укључен граматички моменат представљен синтагмом присвојни придев, а онда се само упућује на основинску реч. На основу примера из Огледне свеске лепо се види да су уређивачи речника нашироко користили могућности аналогних начина тумачења оних изведених речи које имају исту семантичку структуру, односно које припадају истом творбеном типу. Свих ових захтева постављених у Огледној свесци обрађивачи речника нису се касније у целости придржавали, што се види по нешто друкчијој форми дефинисања. Тако he ce, доцније, у РСАНУ ${ }^{9}$ главарев (главаров) дефинисати са који припада главару, а у Огледној свесци је предлагано присвојни придев уз главар.

5. Има, међутим, речи, које су само наоко мотивисане, односно, које су, како Белић каже, полумотивисане, и које се, наравно, не могу ни тумачити као изведена реч. Тако је, рецимо, несумњиво да је главарииа

8 Исп. Српска краљевска академија, Речник српскога књижевног и народног језика, Огледна свеска (глава-глеце), Београд, 1944.

9 Исп. Српска академија наука и уметности, Речник српскохрватског књижевног и народног језика, I-XIV, Београд, 1959-1989. 
изведена реч, што се види по њеном творбеном саставу где се јасно уочава творбена основа главар и творбени формант -ица, а из тога је проистекла и творбена семантика представљена у речнику са жена главар. (Оваква представа значења само је вербални израз творбене структуре). Међутим, именица главар има непотпуну творбену структуру, иако у њој препознајемо коренски (глав-) и формантски део (-ар). Елемент који недостаје је творбено значене, што се одражава и на лексикографску дефиницију која не садржи упућивање на основинску реч, тј. дефиниција је принципски идентична оној која је карактеристична за просту реч. ${ }^{10}$ Ова и њој сличне речи, синхроно гледано, не припадају групацији изведених речи. Оне су, као што је Белић на сличним примерима показао, биле, дијахроно гледано, мотивисане, али то више нису. ${ }^{11} \mathrm{C}$ њима у одређеном смислу, иду заједно и стране речи типа акумулација, имплементација, класификација и сл., чија творбена структура није ни настала у српском језику, па је тешко говорити о њиховој мотивисаности у језику примаоцу.

6. Очито је да не постоји једна општа, унифицирана форма дефиниције свих изведених речи, јер се изведенице међусобно разликују и категоријално, и по начинима творбе, и по творбеним типовима, па и по степену мотивисаности и продуктивности. Кад се, дакле, говори о примени аналогних начина тумачења, онда се мисли на таква тумачења у оквирима појединих творбених начина, творбених типова, модела, па чак и тематски сродних основинских речи. У овом раду ће се анализирати варијације у тумачењу изведених речи на материјалу неких именичких и придевских изведеница.

7. О начинима дефинисања моционих изведеница у неким речницима српског језика већ је писано ${ }^{12}$; анализа је показала доста велику унифицираност унутар појединих речника, али и извесне разлике међу њима. Највећи број изведеница ове групације протумачен је тако што је суфиксални део изведенице представљен изразима типа: женска осо-

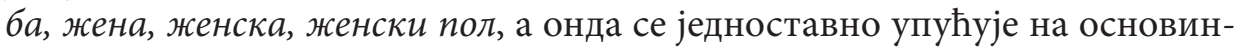
ски део изведенице који је увек комплетан маскулинум. Два најобимнија речника српскохрватског језика, РСАНУ и $\mathrm{PMC} / \mathrm{MX}^{13}$, суфиксални

${ }_{10}$ Исп. деф. у РСАНУ: онај који је по положају први у каквој заједниии, старешина, управтьач.

11 Исто, стр. 25.

12 Исп. Божо Ћорић, Творбено и лексичко значене (наша лексикограбска пракса), НССВД 22/2, Београд, 1993, стр. 257-263.

13 Речник српскохрватскога книжевног језика (Матица српска/Матица хрватска), I-III, Нови Сад - Загреб, 1967-1969; (Матица српска) IV-VI, Нови Сад, 1971-1976. 
део тумаче двојако - са жена и женска особа, при чему у првом речнику предност има конструкција са жена, а у другом са женска особа. Нејасно је зашто није одабрана само једна од две могућности.

8. Међутим, овај начин представљања творбене структуре моционих изведеница није доследно спроведен ни у једном творбеном типу, а уочљива је разлика у овом погледу и међу творбеним типовима. Тако се, рецимо, типови изведеница од маскулинума страног порекла у $\mathrm{PMC/}$ МХ тумаче по моделу женска особа + маскулинум: унијаткиња ж женска особа унијат(а) итд. Остаје нејасно зашто је дактилографкиња ж она која пише на писаћој машини, виолисткиња ж женска особа која свира на виоли, акварелисткиња ж женска особа сликар акварела, бирошкиња женска особа пољопривредни најамни радник, ако се могло поступити исто као и у свим другим случајевима. У исто време РСАНУ има за ове мовиране фемининуме унифицирано тумачење: бирошкиња ж жена бироч, дактилографкиња ж жена дактилограф, виолисткиња ж жена виолист. ${ }^{14}$

9. Било је, као што смо видели, предлога да се и присвојни придеви на -ов/-ев дефинишу типизирано ${ }^{15}$, за шта заиста постоје чврсти разлози: имају исти суфикс, сви се граде искључиво од именица, а заједничко им је и основно значење (може се описати као: однос према ономе што је именовано основинском речи). Међутим, из више разлога тумачење ових изведених придева није тако једноставно како би се могло претпоставити на основу наведених заједничких момената. Одређене семантичке специфичности јавиће се већ и због различитих категорија именица у основи придева, а то могу бити именице са значењем лица (властите и заједничке), са значењем биљака, животиња, а и именице које значе што

14 Примера неуједначености у тумачењу мовираних изведеница има код свих творбених типова ове категорије, код неких више, код неких мање, али то не нарушава општи утисак о високом нивоу унифицираности дефиниција. У $\mathrm{PMC/MX} \mathrm{торбарка} \mathrm{и} \mathrm{фарбарка} \mathrm{су} \mathrm{тумачене} \mathrm{као} \mathrm{жена} \mathrm{торбар,} \mathrm{жена} \mathrm{барбар,}$ тифусарка као болесница од тифуса, тучарка као она која чува туке, брашнарка као женска особа која продаје брашно итд., али према оваквим случајевима стоји неупоредиво већи број примера унифицираног дефинисања типа женска особа+маскулинум на -ар (стражарка женска особа стражар, беспосличарка женска особа беспосличар итд.). У истом овом речнику се тршавица тумачи упућивањем на маскулинум - женска особа тршаваи, а ћелавица се тумачи синтагмом ћелава жена; безверница је женска особа безверник, а безумница је безумна женска особа; терачица је жена терач, везачица је женска особа везач, али је узимачица она која узима итд.

15 Исп. Огледна свеска, стр. XI. 
неживо. Побочна значења ових придева зависиће и од тога казује ли се однос према одређеном (најчешће) или неодређеном лицу (ређе). Кад су у основи именице које значе биљке, онда је лепеза значења веома широка, што је узроковано, с једне стране, чињеницом што такве именице значе и биљку и плод, а с друге стране зато што значење не зависи само од значења основе, него и од именице уз коју придев стоји. Значење сваког придева било би најкомплетније протумачено кад би се показало у контексту са именицом уз коју придев стоји. То значи да би свако потпуније тумачење изведеног придева подразумевало дефинисање свих типова колокација, а то је не само нерационално, већ и немогуће. Сад је, дакле, јасно зашто није могла да буде прихваћена сугестија аутора уводног текста Огледне свеске.

9.1. Међутим, ако је немогућа типизирана дефиниција свих придева на -ов, то не значи да у одређеним групацијама такве дефиниције не би могло да буде. Ако се, на пример, издвојено посматрају придеви овог типа са основинском именицом исте семантичке и тематске скупине, онда се могућност типизираног тумачења знатно увећава. То даље значи да би се придеви од именица које значе називе дрвећа могли, генерално узевши, једнообразно дефинисати, пре свега у основном, а и у неким побочним значењима. Суфиксни део изведенице може се интерпретирати изразима типа: који припада, који је од, који се односи на, који је начиюен od, а затим се само упути на именицу у основи. У принципу, унифицирано значење подразумевало би и идентичан редослед понуђених решења. Како ово изгледа у лексикографској пракси показаћемо на примеру придева изведених од именица као што су: буква, бор, бреза, граб, јавор, јела, храст и сл. Упоредна анализа на материјалу РМС/MХ показује да је унифицираност ограниченог домета: четрнаест одабраних придева има десетак мање више различитих форми тумачења. Разлика се тиче и броја значења, и њиховог редоследа и њихове форме. ${ }^{16}$

16 Исп. следеће примере:

а) храстов који је од храста; који се односи на храст: шума...

б) буков који припада букви, који је од букве, од букава: лист, итап; РСАНу под буков има: који се односи на букву (који припада букви, који потиче од букве, који је начињен од букве и сл.).

врбов који припада врби, који је од врбе

јасиков који припада јасиии, који је од јасике

в) боров који је од бора; РСАНУ уопште нема боров

брезов који је од брезе; РСАНУ има ово: који припада брези, који се састоји од брезе; који је начињен од брезе, брезовине. 
9.2. У једној другој групацији изведених речи, међутим, постигнута је готово апсолутна унифицираност. Реч је о именицама изведеним помоћу суфикса -ина од напред наведених придевских основа, а које су протумачене по моделу ХРАСТОВО (БАГРЕМОВО, КЕДРОВО...) ДРВО, где је именица дрво ознака суфиксалног дела значења. Из неразумљивих разлога јаворовина је протумачена именичком синтагмом са падежним атрибутом: дрво од јавора. Ни група придева изведених од назива годишњих доба, иако малобројна, нема у целости типизирану дефиницију. ${ }^{17}$ Рецимо, придеви летюи и зимски једнако су дефинисани, док друга два придева имају друкчију, опширнију формулацију. Нејасно је зашто и ова два придева немају типизирану дефиницију.

10. Као пример одсуства типизиране дефиниције може се узети и трочлани низ који се састоји од глагола на -ирати (-овати, -исати), именица на -юе и именица на -ација типа: акумулирати - акумулиране - акумулација, алтернирати - алтернирағе - алтернација и сл. Са творбеног становишта сасвим јасну структуру имају глаголске именице на -юе изведене од споменутих глагола, а које се сасвим лепо уклапају

јасенов који је од јасена; РСАНУ: који се односи на јасен (који припада јасену, који је од јасена, који се састоји од јасенова и сл.).

г) јабланов који припада јаблану; РСАНУ: који је од јаблана, који се односи на јаблан.

крушков који припада крушки, РСАНУ: који је од крушке (крушака), који се односи на крушку (крушке).

д) кедров који је од кедра, који припада кедру; РСАНУ: који је од кедра.

Ђ) грабов који се односи на граб; који је од граба (исто као код храстов, само обрнут редослед значења); РСАНУ има: који се односи на граб (који је од грабовине и сл.).

е) јелов који припада јели, који је начиғен од јеловине; РСАНУ: који се односи на јелу (који припада јели, који потиче од јеле, који је начињен од јеле, јеловине и сл.).

ж) јаворов који припада јавору, који је од јаворовог дрвета; РСАНУ: 1. који припада јавору... 2. који је начињен од јаворовог дрвета, од јаворовине...

з) багренов се упућује на багремов, а овога уопште нема: PCAНУ има: багремов који се односи на багрем; који је од багрема.

${ }_{17}^{17}$ Исп. примере:

пролетни=пролећни који се односи на пролеће, који се догађ а у пролеће, који се изводи у пролеће

летьи који се односи на тето

јесенски=јесењи 1. који припада јесени; који се врии у јесен;

2. који је као јесен

зимски који се односи на зиму. 
и у начин дефинисања ове творбене категорије у речницима. Друга два члана овог низа творбено су спорна. Једни научници у њима виде интернационализме, а други их сматрају изведеним речима, при чему би, кад је њихов међусобни однос у питању, именице биле мотивисане глаголима, а не обрнуто. И доиста, није спорна чињеница да ове категорије речи имају исти корен, јер је то очито, али је спорна њихова творбена веза, ако она уопште постоји. Таква веза би требало да резултира одговарајућим творбеним значењем, како мора имати свака изведеница, а она овде углавном изостаје. Постоји, међутим, једна друга група сродних изведеница на -ащија које имају нешто друкчији комплекс творбених веза, па и друкчију форму самог творбеног форманта. То су именице као: моторизација, аутомобилизација, хибридизација, канализација, категоризација и сл. Према овим именицама са формантом -изација стоје одговарајући глаголи и одговарајуће друге именице као чланови трочланог низа у коме су творбене везе сасвим јасне и провидне, што се показује и тумачењем ових речи путем упућивања на основинску именицу. Да је овај творбени тип продуктиван показује одскора актуелна реч компјутеризација. Додуше, ни позајмљивање страних речи на -ација није замрло, што опет показује трочлани низ имплементација - имплементиране - имплементирати. Не задржавајући се више на творбеном аспекту ових речи, додаћемо само да треба одвојено анализирати речи на -ација и -изација.

10.1. Из ових нејасноћа творбене природе произилазе и недоследности у начинима дефинисања речи из низова типа акумулација - акумулираюе - акумулирати. ${ }^{18}$

Рецимо, именице на -юе и на -ација у великом броју случајева су синоними, али се то у тумачењима ових речи ретко кад региструје. ${ }^{19}$

Однос између именице на -ација и истокорених глагола тумачи се тројако: а) засебним преводом дотичних посуђеница, као да међу њима и нема никакве везе на плану израза и садржаја; б) каткад се глагол дефинише упућивањем на именицу, што показује да централно место у овом

18 Наравно, ово се не односи на глаголску именицу на -юе, чија се дефиниција поклапа у свему са дефиницијама ових именица уопште. Међутим, ова глаголска именица представља заправо само језички потенцијал, а не обавезну језичку творевину, па тих именица и не мора да буде у речнику, и често их и нема тамо. Али да је то продуктивна категорија показује и сасвим свежа потврда именице коалиране. (Исп.: Уосталом, до коалирања бивщих комуниста и либерала (ако га буде), моћи ће да дође и касније... Политика, Београд, 13.8.1996).

19 У ретке примере иде: класификација класифицираюе, оцена, оцениване. 
трочланом низу припада заправо именицама на -ација; ${ }^{20}$ в) комбинацијом прва два начина. ${ }^{21}$

11. Спроведена анализа неких изведених именица и придева показује да постоје широке могућности примене типизираног начина тумачења речи. Тиме би се постигла економичност, јасност, прегледност и указало на системност лексичког материјала. У речницима српског језика углавном се водило рачуна о томе да се изведене речи дефинишу на специфичан начин; уочљива су, наиме, настојања да се њихова специфична семантичка структура и у лексикографском делу сачува, односно да се изведенице истих творбених типова што уједначеније дефинишу. Ова настојања имала су у неким случајевима већи, а у другим мањи домет. Висок степен доследности постигнут је при тумачењу глаголских именица на -юе и именица субјективне оцене, док се у неким другим творбеним категоријама и типовима могу уочити различита одступања од очекиваних типизираних начина дефинисања.

Божо Чорич

\section{ВАРИАНТЫ ТРАКТОВОК ПРОИЗВОДНЫХ СЛОВ В ТОЛКОВЫХ СЛОВАРЯХ СЕРБСКОГО ЯЗЫКА}

Резюме

В настоящей работе анализируются различные трактовки производных слов на материале некоторых дериватов существительных и прилагательных. Проведенный анализ показал, что существуют широкие возможности применения типизированного способа толкования производных слов в лексикографических трудах. Данная возможность в большой степени использовалась в сербской лексикографии, и поэтому очевидны попытки производные слова одинаковых словообразовательных типов последовательно определять. Такие попытки были в одних случаях более, а в других случаях менее результативными.

${ }^{20}$ Исп. примере као: асимилирати (из)вршити асимилацију, агитирати вриити агитацију, експроприрати=експроприсати (из)вриити експропријаичију итд.

${ }^{21}$ Исп. примере типа: еманципирати=еманциповати (из)вршити еманципацију, ослободити (некога од нечега), вакцинирати цепити (се), давати вакцинуу. 